\title{
PRODUÇÃO DE VÍDEO EDUCATIVO POR LICENCIANDOS: UM ESTUDO SOBRE RECEPÇÃO FÍLMICA E MODOS DE LEITURA ${ }^{1}$
}

\author{
Wagner Gonçalves Bastos* \\ Luiz Augusto Coimbra de Rezende Filho** \\ Américo de Araujo Pastor Junior**
}

RESUMO: Neste trabalho, analisamos a produção e a recepção de um vídeo de autoria de alunos de uma Licenciatura em Biologia a fim de identificar o endereçamento e o significado preferencial de acordo com seus produtores e com as leituras feitas por um grupo de espectadores. Para isso, analisamos o vídeo, entrevistamos os produtores e fizemos uma exibição para seus colegas de turma. Os resultados indicam que o grupo, em sua maioria, identificou um significado preferencial ligeiramente diferente daquele concebido pelos produtores, contudo, avaliou como adequadas as estratégias de endereçamento utilizadas no vídeo. Além disso, notamos que mesmo a produção de um vídeo com intenções educativas explícitas está imersa em indeterminações e que os lugares construídos para o espectador podem ser diversamente reconfigurados por ele.

Palavras-chave: Vídeo educativo. Estudos de recepção fílmica. Ensino de biologia.

\section{PRODUCCIÓN DE VIDEO EDUCATIVO POR LICENCIANDOS: UN ESTUDIO ACERCA LA RECEPCIÓN FÍLMICA Y MODOS DE LECTURA}

RESUMEN: En este trabajo, analizamos la producción y la recepción de un video producido por alumnos de una Licenciatura en Biología con fines de identificar el aderezamiento y el significado preferencial de acuerdo a sus productores y con las lecturas hechas por un grupo de espectadores. Para ello, analizamos el video, entrevistamos los productores e hicimos una exhibición para sus compañeros de clase. Los resultados indican que el grupo, en su mayoría, identificó un significado preferencial ligeramente diferente de lo que fue concebido por los productores, no obstante, evaluó como adecuadas las estrategias de aderezamiento utilizadas en el video. Además, notamos que mismo la producción de un video con intensiones educativas explícitas está inmersa en indeterminaciones y que los lugares construidos para el espectador pueden ser diversamente reconfiguradas por él.

Palabras clave: Video educativo. Estudios de recepción fílmica. Enseñanza de Biología.

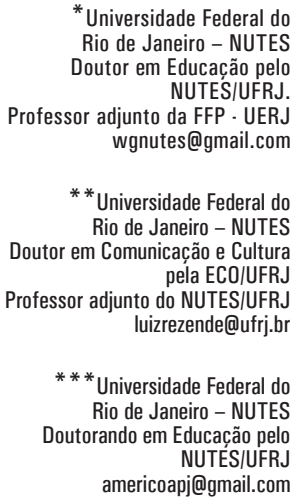

Universidade Federal do Rio de Janeiro - NUTES NUTES/UFRJ. diunto da FFP . UER wgnutes@gmail.com

niversidade Federal do - NUTES pela ECO/UFR. o do NUTES/UFR americoapj@gmail.com 
EDUCATIONAL VIDEOPRODUCED BY PRE-SERVICE TEACHERS: A STUDY ON VIDEO RECEPTION AND MODES OF READING

ABSTRACT: In this paper, we examined the production and reception of a video produced by Biology pre-service teachers in order to identify the mode of address and the preferred meaning according to its producers and according to the readings made by a group of spectators. For this, we analyze the video, interviewed the producers and screened the video for their classmates. The results indicate that the group mostly identified a slightly different preferred meaning than the one conceived by the producers. Neverthelessthey assessed as appropriate the strategies for addressing used in the video. Besides we noted that even the production of a explicit educational purposevideo is immersed in indetermination and that the places constructed for the viewers can be diversely reconfigured by them.

Keywords: Educational video. Film reception studies. Biology teaching. 


\section{INTRODUĈ̣̃O}

O uso de vídeos na educação tem sido cercado por muitos pressupostos sobre suas vantagens e seus benefícios para o processo de ensino-aprendizagem. Para muitos autores, o uso do vídeo na escola traz, por exemplo, várias possibilidades para despertar a atenção ou reforçar o interesse dos alunos, estimulando sua curiosidade e aumentando sua motivação (FERRÉS, 1996; ARROIO; DINIZ; GIORDAN, 2005, ARROIO; GIORDAN, 2006). Worth (1981) aponta, no entanto, que alguns desses pressupostos têm se mostrado tão consensuais e tão implicitamente verdadeiros que têm sido aceitos sem a exigência de mais pesquisas ou confirmação. Segundo este autor, sustenta-se que: (1) o audiovisual é psicologicamente superior às palavras; e (2) o filme tem potencial inexplorado para o que as palavras têm falhado em fazer. Como suposta "linguagem universal", filmes e vídeos apresentariam, então, grande potencial para ensinar de maneira mais eficiente, comunicando de forma multimodal, multissensorial, independentemente das especificidades de faixa etária ou de cultura.

No entanto, esses pressupostos não têm sido pensados no que toca questões colocadas pelas condições específicas da recepção audiovisual em sala de aula, relacionadas, por exemplo, às diferenças culturais que estão implícitas nos filmes, à especificidade dos conteúdos científicos e às suas formas de apresentação por meio de diferentes modelos de narrativa audiovisual. Tais fatores podem se constituir em fontes de resistência dos alunos ao material audiovisual e podem colocar em xeque as vantagens que lhe são inicialmente atribuídas, como as citadas por Worth (1981) e outros autores (FERRÉS, 1996; ARROIO; DINIZ; GIORDAN, 2005; ARROIO; GIORDAN, 2006).

Para investigar que elementos afetam e condicionam o processo educacional mediado pelo audiovisual, julgamos ser necessário saber mais sobre como o aluno é construído e se constrói como espectador de obras audiovisuais em sala de aula e como faz inferências sobre o que lhe é exibido, tendo por base a cultura e as experiências socioculturais em que está imerso. Além disso, cabe saber como estas inferências podem se diferir entre os diversos públicos estudantis e as diversas situações de exibição e como o aluno é abordado como espectador de conteúdos científicos.

Assim, neste artigo, trazemos os estudos de recepção já consolidados na área da Comunicação para colaborar com as pesquisas educacionais sobre o uso do audiovisual na educação em ciências e para ampliar o conjunto de questões que se relacionam a este tema de pesquisa. Além disso, esperamos lançar alguma luz sobre os pressupostos que cercam essa temática, como indicado acima, e contribuir para discuti-los. Apresentamos, então, um estudo da produção e da recepção de um vídeo elaborado por alunos de Licenciatura em Biologia de uma universidade pública do Estado do Rio de Janeiro. Os objetivos deste estudo foram: identificar o endereçamento e o significado preferencial do vídeo produzido para ser utilizado em aulas no Ensino Médio e compará-los com as leituras produzidas 
pelos alunos que o viram; identificar o modo de leitura construído no contexto da atividade de exibição; e descrever e analisar as posições de leitura adotadas pelos espectadores em relação ao vídeo produzido.

Este estudo ainda se encontra em desenvolvimento, embora a apresentação do vídeo produzido a uma turma de Ensino Médio já tenha sido feita. A identificação dos modos e das posições de leitura por esses alunos ainda está sendo investigada, e os resultados serão publicados em outro momento.

\section{MARCO TEÓRICO}

A maioria das decisões sobre a narrativa de um filme, seu acabamento e sua aparência final é feita à luz de pressupostos conscientes e inconscientes sobre "quem" são seus possíveis públicos espectadores, o que estes desejam e como veem os filmes (ELLSWORTH, 2001). Tal situação não é diferente para os filmes científicos e os educativos. Além das considerações que devem ser levantadas sobre as características do conteúdo a ser apresentado e as orientações curriculares que guiam a produção do material educativo audiovisual, essas obras também se constroem a partir de pressuposições sobre quem são seus espectadores em potencial.

A forma como é construída e projetada essa relação entre um filme e a experiência provável do espectador é chamada pelos teóricos do cinema de modo de endereçamento (ELLSWORTH, 2001). Este conceito fundamenta-se em argumento segundo o qual, para que um filme "funcione", o espectador deve entrar em uma relação particular com a história e o sistema de imagem do filme. Refere-se ao empenho pela "melhor comunicação", ao ajuste que os produtores fazem nos textos fílmicos para que eles sejam compreendidos de uma determinada maneira por um público imaginado. Por outro lado, refere-se também às adaptações feitas pelos receptores em seus posicionamentos para ler o texto audiovisual de maneiras que podem não ter sido previstas pelos produtores, mas são mais ou menos "compatíveis" com o texto (ELLSWORTH, 2001). Morley (1996) chama de destinação esse esforço dos produtores em buscar abordar o público de uma determinada maneira, como forma de estabelecer uma relação específica com ele.

Entretanto, tanto no cinema quanto nas escolas, os produtores audiovisuais estão distanciados dos espectadores reais ou concretos, e os espectadores que eles supõem existirem nunca são apenas ou totalmente quem esses produtores "pensam" que eles são. Esse é um dos motivos pelos quais os espectadores podem ler os filmes em direção diversa ou até contrária à que seus modos de endereçamento indicam. Tal possibilidade é problemática para a produção de sentido, já que pode levar a resistências às perspectivas ou aos conteúdos do filme (ELLSWORTH, 2001) e nos coloca uma questão importante para pensarmos o uso de filmes e vídeos na educação. Assim como os produtores de cinema não podem controlar a forma como os espectadores entendem o que é endereçado 
nos filmes, os professores também não podem controlar totalmente a produção de sentido que seus alunos, como espectadores, fazem quando assistem a produções audiovisuais durante uma aula ou uma atividade educativa. Esse problema não tem sido suficientemente contemplado pelas pesquisas sobre o uso de audiovisuais na educação em ciências.

Essa reflexão sobre o endereçamento nos leva à questão da recepção, da produção de sentido, como fenômeno multidimensional, não linear e condicionado tanto por elementos previamente determinados quanto por elementos não determinados. Os estudos de recepção ganharam relevância no campo da Comunicação quando se deslocaram as preocupações com o problema do estudo tradicional do polo da produção para as pesquisas sobre o polo do consumo, sobre a recepção, reconhecendo-se este último como local estratégico e relevante de negociação e estruturação de significados (LEAL, 1995), por ser fundamentalmente pautado pelas indeterminações das leituras produzidas pelos sujeitos. Tendências mais contemporâneas, no entanto, mostraram que o polo da produção implica certas determinações que podem condicionar e estruturar a produção de sentido. Tem sido apontada, portanto, a necessidade de investimento em pesquisas que se fundamentem em uma visão holística sobre os processos da comunicação audiovisual, envolvendo de forma complexa e indissociável os dois polos: produção e recepção (DEACON, 2003).

Assim, os estudos sobre recepção na contemporaneidade têm destacado não só o papel ativo (no que diz respeito à produção de resistências e adesões) e criativo (no que diz respeito à produção de leituras variadas que se alimentam de referências diversas) do espectador, mas também o grau de determinação e controle que pode ser exercido pelo produtor na maneira como ele próprio endereça a obra ou como escolhe e delimita determinados "significados" e "leituras preferenciais". Por isso, esses estudos podem proceder a uma dupla investigação: de um lado, sobre as próprias características da obra e de sua produção, procurando identificar o significado preferencial pensado pelos produtores, isto é, o sentido por eles pretendido e desejado para a obra (HALL, 2003a) e/ou o seu modo de endereçamento; por outro lado, pode-se proceder a um estudo sobre as leituras e os sentidos produzidos pelos espectadores em diferentes dimensões ou níveis de relação e atribuição de significado e valor à obra. Pode-se também buscar identificar como um contexto determinado de exibição pode produzir variações sobre a forma como uma obra audiovisual é compreendida e experienciada, dando origem a diferentes modos de leitura (ODIN, 2005).

Ao criar um modelo de análise de recepção fundamentado na relação entre os processos de codificação e decodificação, Hall (2003b) inaugurou um novo campo de pesquisa destacando a relação circular entre a produção e a recepção das mídias. De acordo com Hall (2003b), as pesquisas mais tradicionais de comunicação de massa utilizavam modelos empíricos positivistas, que entendiam a comunicação como um processo em que o emissor originaria a mensagem, estruturada de forma completa sobre seu sentido, e o receptor apenas decodificaria 
os códigos anteriormente estruturados pelo emissor. Segundo essa tradição, toda comunicação tenderia à perfeição, pois a mensagem produzida pelo emissor seria a mesma percebida pelo receptor.

Hall (2003a) problematiza essa atividade de decodificação mostrando como ela é complexa e plena de indeterminações e variáveis. Para Hall (2003a), nem a produção da mensagem nem sua recepção são atividades transparentes, como podem parecer, uma vez que a mensagem pode ser multirreferencial, e o receptor pode interpretá-la também de acordo com uma infinidade de sistemas de referência (social, cultural, profissional, ideológico, de escolaridade, etc.), que são em geral distintos dos referenciais usados na codificação. Esse fato pode produzir uma diversidade de leituras e posicionamentos frente à obra audiovisual.

Para Hall (2003a), existiriam três posições possíveis de decodificação/ leitura: dominante, negociada e de oposição. Todas essas posições se relacionam à forma como o espectador apreende o que ele entende como o significado preferencial da obra, tal como parece estar definido por seu produtor. Assim, o significado preferencial está mais ligado ao âmbito da codificação, representado pelo sentido adotado pelo produtor na elaboração de uma "mensagem", e a leitura preferencial, à decodificação, não homogênea, ocorrendo diferentes leituras, que correspondem às leituras realizadas pela maioria dos espectadores (SCHRØDER, 2000).

$\mathrm{Na}$ leitura dominante (ou hegemônica), ocorre uma posição de transparência ideal e de equivalência entre codificação e decodificação, de tal forma que a leitura realizada pelos espectadores corresponde quase que perfeitamente ao significado preferencial do texto. Na leitura de oposição (ou contestatória), existe o oposto: o espectador decodifica a mensagem retirando do texto uma leitura que se opõe ao significado preferencial; ele olha as mesmas figuras, mas vê outro lado delas. Já na leitura negociada, que, segundo Hall (2003a), é a mais comum, o espectador decodifica a mensagem dentro de um espaço negociado, preenchido por diferentes posições situadas entre a posição preferencial e a posição de oposição.

Schrøder (2000) ampliou o modelo de Hall (2003b) ao identificar e incorporar outras dimensões de produção de sentido. Este modelo divide-se em dois grupos: um que corresponde aos elementos constituintes das "leituras", e outro, aos das "implicações". Existem quatro dimensões de leitura no primeiro grupo: (1) Motivação: refere-se ao modo como os indivíduos estabelecem que uma determinada mensagem audiovisual merece ser lida e à maneira como fatores diversos, cognitivos e afetivos, podem determinar a motivação para se ler ou não dada obra; (2) Compreensão: refere-se a como os espectadores compreendem signos verbais e visuais, como atribuem uma determinada identidade ao que veem/leem, como os signos são decodificados de acordo com fatores macrossociais (classe, gênero, raça) e microssociais (escolaridade, relações situacionais, cultura); (3) Discriminação: refere-se a como os espectadores podem adotar ou não uma posição esteticamente crítica frente ao texto fílmico e a como e quanto uma determinada leitura está caracterizada por uma consciência sobre o caráter de construção e de artifício de todo produto audiovisual. Esta dimensão inclui ainda um elemento de discri- 
minação estética, em dois eixos paralelos: de imersão fraca a imersão intensa, e de distanciamento fraco a distanciamento intenso; (4) Posição: refere-se ao nível ideológico "subjetivo" (manifestado pelos sujeitos) e a como os espectadores se posicionam pessoalmente em relação ao sentido que compreendem da mensagem. Esta dimensão de leitura varia da aceitação até a rejeição da posição textual identificada pelo leitor e dos diversos elementos do texto a que ele atribui tal posicionamento.

O segundo grupo, o das "implicações", está relacionado com a possibilidade de utilização do significado social das leituras como ferramenta para ações políticas e não será discutido neste trabalho.

Além das diversas dimensões da leitura, o contexto de exibição de uma obra audiovisual também é relevante para os estudos de recepção. Segundo Odin (2005), de acordo com o contexto de exibição, o espectador recebe imposições de leitura dependentes das instituições - escolar, familiar, científica, profissional - a que este contexto estiver submetido. Assim, ver um filme em uma aula de biologia, por exemplo, sugere a mobilização de um processo de leitura distinto do que ocorreria se o mesmo filme fosse visto no cinema, em outro espaço ou com outra finalidade.

Ao ver um filme, o público costuma mobilizar vários modos de produção de sentido. No entanto, pode ocorrer que o filme por si só não tenha muito peso, diante das imposições do contexto, na escolha dos modos de produção de sentido. De uma mesma "projeção fílmica", podem nascer diferentes "textos fílmicos", de acordo com o público que o vê. Em alguma medida, é o contexto que constrói o texto adotado pelo público. Worth (1981) acrescenta a esse aspecto a ideia segundo a qual um filme não tem sentido em si, mas adquire sentido na sua relação com um sujeito que o percebe. A construção do texto pelo espectador é feita sob a pressão das diversas determinações que o cercam, sem que frequentemente se tenha consciência disso.

Um filme geralmente fornece indicações dos modos como deseja que ocorra sua leitura. É nesse ponto que reencontramos a questão do endereçamento, já que essas indicações podem se apresentar em elementos de seu conteúdo, no sistema predeterminado de estilos adotado, ou seja, em seu modo de endereçamento propriamente dito. Tudo isso deve ser relacionado e analisado de acordo com as imposições do contexto de visualização do filme (ODIN, 2005).

Odin (2005) caracteriza um conjunto de nove modos de leitura, dos quais destacamos apenas os que se relacionam mais proximamente a esta pesquisa: (1) Modo documentário: ver um filme para obter informações sobre a realidade das coisas do mundo, como em filmes históricos, etnográficos e documentários; (2) Modo argumentativo/persuasivo: ver um filme para poder elaborar um discurso, para convencer, para argumentar e debater questões consideradas relevantes; (3) Modo estético: ver um filme interessando-se pelo trabalho feito com as imagens e os sons, pela forma como a obra é construída esteticamente; (4) Modo privado: ver um filme voltando-se para a vivência pessoal ou a de seu grupo, buscando 
rememorar ou compartilhar experiências restritas ao grupo ao qual se pertence, reforçando identidades e cumplicidades, tal como ocorre frequentemente na exibição de filmes e vídeos domésticos.

Para identificar o modo de leitura dominante na exibição de uma obra audiovisual, de acordo com Odin (2005), é preciso analisar o contexto dessa exibição e as suas implicações na produção de sentido adotada pelos espectadores, tendo em vista que o espectador recebe imposições na leitura que faz. De acordo com a instituição a que o contexto esteja relacionado e com as informações exteriores à obra que circulam ao seu redor (como cartazes de divulgação, apresentação e/ou material didático introdutório), a obra receberá diferentes indicações sobre como deve ser vista e qual é seu sentido.

Para entendermos, então, os limites e as potencialidades da utilização de recursos audiovisuais em sala de aula, precisamos analisar a experiência dos estudantes como espectadores nesse espaço. Precisamos conhecer que experiências lhes permitem criar resistência ou aceitação a produções e atividades educativas com audiovisual - ou mesmo às disciplinas escolares, tendo em vista que suas preferências e resistências podem vir a se evidenciar em sala de aula durante a exibição de um vídeo. Levando tais ideias em consideração, estudos de recepção audiovisual podem ser feitos para se entender melhor como as atitudes dos alunos se desenvolvem frente aos mais diversos tipos de atividades e produções audiovisuais e como eles se posicionam, resistem ou aderem a essas atividades e produções.

\section{METODOLOGIA}

Neste trabalho, pesquisamos a produção e a recepção de um vídeo produzido por licenciandos em Biologia. Para estudar a produção, analisamos as respostas dadas por seus produtores em uma entrevista, além de analisarmos o vídeo que realizaram. Para estudar a recepção, fizemos uma exibição do vídeo, observamos o contexto desta exibição e aplicamos um questionário aos espectadores.

\section{A turma de licenciandos e 0 contexto do estudo}

Neste estudo, uma atividade de produção e exibição de vídeos foi proposta a uma turma de alunos do quarto período do curso de Licenciatura em Biologia de uma universidade pública do Estado do Rio de Janeiro. Todos os participantes estavam na faixa dos 21 anos. O tema a ser desenvolvido pelos alunos era "Corpo humano e suas defesas: atitudes para uma vida saudável". A turma foi devidamente dividida em cinco grupos, e lhes foi solicitado que procurassem endereçar as produções a alunos de Ensino Médio, na faixa etária de 15 a 18 anos, para que os vídeos produzidos pudessem ser apresentados como complemento ao ensino em aulas de biologia cujo tema abordado fosse a saúde. Cada grupo produziu um vídeo. 
Os alunos passaram por uma capacitação para compreenderem e utilizarem, na produção do vídeo, os conceitos de endereçamento/sentido preferencial - conforme Ellsworth (2001) e Hall (2003b) -, assim como os possíveis modos de leitura/ exibição - de acordo com Hall (2003b), Schrøder (2000) e Odin (2005). Essa capacitação ocorreu em seis horas de aula, por meio de leitura e discussão de um texto extraído e adaptado de Pastor Junior (2012).

Após todos os vídeos terem sido produzidos e exibidos a todos os grupos da turma, foi escolhido pelos participantes um vídeo que seria novamente apresentado para participar do estudo de recepção. Foi sugerido que os alunos adotassem como critério para escolha a adequação do vídeo aos objetivos propostos, ou seja, eles deveriam avaliar qual vídeo teria cumprido da melhor forma os objetivos da atividade.

Os 17 alunos que não participaram da produção do vídeo escolhido, após a segunda exibição, foram convidados a responder um questionário, que pretendia investigar o endereçamento e o significado preferencial pretendido pelo vídeo apresentado. Esse questionário não solicitou identificação do respondente. A investigação do endereçamento e do significado preferencial com uma audiência que não era aquela explicitamente endereçada pelo vídeo se fundamentou na suposição de que os licenciandos não produtores agiriam como analistas e avaliariam o vídeo de uma perspectiva que combinasse atributos de uma audiência regular e de uma audiência especializada, já que eles passaram por um treinamento sobre os conceitos investigados neste estudo. Assim, eles poderiam avaliar se o vídeo havia ou não elaborado e utilizado estratégias de endereçamento adequadas, conforme o que tinha sido aprendido durante o curso.

Já os cinco alunos produtores do vídeo escolhido foram entrevistados para se averiguar como haviam pensado estruturar o vídeo para o endereçamento/ significado preferencial pretendido. O roteiro para essa entrevista continha seis perguntas, que, em síntese, tratavam de investigar os objetivos do vídeo, a mensagem que desejavam apresentar, como se estruturou o vídeo e se justificou a escolha dos recursos estéticos utilizados. A entrevista foi feita em grupo e durou cerca de 25 minutos.

Como a apresentação dos vídeos foi feita em sala de aula apenas para alunos da disciplina e para o professor, e como todos esses alunos tinham participado pelo menos da atividade de produção de um vídeo, pode-se deduzir que os sujeitos deste estudo tinham algum tipo de experiência em produção audiovisual e, principalmente, sobre o tema abordado nos vídeos. Além disso, é importante ressaltar que esses alunos cursavam juntos outras disciplinas e, em alguns casos, mantinham entre si vínculos afetivos.

\section{Descrição e análise do vídeo escolhido}

O vídeo analisado tem duração de nove minutos e 45 segundos. É uma edição feita com imagens, fotografias e pequenos trechos de vídeos profissionais 
disponíveis na internet, intercalados e divididos em três seções, com ênfase em assuntos distintos: (1) mecanismos de defesa naturais do nosso organismo; (2) perigo do uso de anabolizantes esteroides; e (3) risco da ingestão excessiva de bebidas alcoólicas. Dentre as imagens escolhidas, observamos fotos de artistas jovens (como Sabrina Sato e modelos do programa "Fantástico"), modelos de ambos os sexos, caricaturas engraçadas de situações sérias e imagens de corpos excessivamente musculosos, órgãos humanos doentes, lesões de pele, abscessos, tumores, dentre outros.

Os autores intercalaram quadros legendados entre essas imagens e os vídeos (com suas músicas originais), procurando produzir uma sequência lógica. Utilizaram, ainda, três músicas: "Requiem for a Dream", do filme de mesmo nome, "Sexy and I Know it", do grupo LMFAO3, e "Clocks", do grupo Coldplay . Todas foram usadas em sua versão instrumental, são famosas e ouvidas pela faixa etária à qual o vídeo deveria ser endereçado, mas não foram indicadas no vídeo suas produtoras musicais. Usaram, ainda, o diálogo direto com seu público, por exemplo, quando dizem: "Você que é jovem...", ou "Se liga!". Do modo como foi feito, o vídeo apresenta-se de forma similar a um documentário de propaganda, relatando quais são as doenças provocadas pelo uso excessivo de anabolizantes e de bebidas alcoólicas e enfatizando, sobretudo, os riscos que se corre com esses consumos. Tenta, embora em poucos momentos, estimular a sensibilidade do espectador jovem quando diz "Se liga!" ou "Porém... alguns querem dar uma de espertos...".

As escolhas estéticas, de narrativa, de imagens, de efeitos e de edição resultaram num vídeo que intercala conhecimentos científicos e conteúdos moralistas, na tentativa de convencer seus espectadores dos riscos de determinados hábitos. É um vídeo com mensagem pronta, normativa, que explora imagens de modo sensacionalista, tentando ser enfático e impactante. $\mathrm{O}$ vídeo apela para a fala científica para tentar dar maior credibilidade ao que é dito e para atingir seu espectador na sua ética, na sua moral, procurando fazê-lo mudar de atitude ou não adotar determinados tipos de comportamento. Usando a credibilidade do científico, procura indicar "normas corretas de conduta" e, explorando situações limítrofes de uso de anabolizantes e bebidas alcoólicas, tenta causar impacto nos espectadores e medo quanto a esse uso.

\section{RESULTADOS}

\section{Sobre a produção do vídeo}

A avaliação da entrevista com os produtores foi feita por meio da análise de conteúdo, a partir da decifração estrutural e da transversalidade temática, tal como proposto por Bardin (2011). De acordo com essa autora, a reunião dessas duas fases se configura como uma tentativa de conseguir um poder de generalização/comparação entre as análises sem ter de abrir mão da complexidade subjetiva 
que constitui os eventos discursivos formadores dos dados coletados.

Para Bardin (2011), a análise de conteúdo é uma estratégia para ir além das aparências dos eventos comunicativos, uma atitude de vigilância crítica diante da ilusão de transparência dos fatos sociais. É a manipulação da mensagem (conteúdos e expressão desse conteúdo) para evidenciar indicadores que permitam inferir sobre uma realidade outra que não a da mensagem, ou seja, é uma busca de outras realidades por meio da mensagem. Não se trata de um instrumento, mas de um leque de apetrechos que devem ser configurados de acordo com os objetivos da análise. Segundo a autora,

A análise de conteúdo tenta compreender os jogadores e/ou o ambiente do jogo em um momento determinado. Contrariamente à linguística, que apenas se ocupa das formas e suas distribuições, a análise de conteúdo toma em consideração as significações (conteúdo), eventualmente sua forma e a distribuição destes conteúdos e formas (índices formais e análise de coocorrência). (BARDIN, 2011, p. 43)

Sendo assim, a análise começou com uma leitura flutuante da transcrição da entrevista. A seguir, foi feita uma análise temática dessa transcrição, buscando-se reunir em categorias maiores os temas identificados. Em seguida, foram analisadas a sequência de interação e, finalmente, as enunciações, de forma mais cuidadosa. Embora o roteiro para a entrevista contivesse seis perguntas, a leitura flutuante e a subsequente análise temática permitiram encontrar três blocos temáticos, ainda que não se constituíssem como partes estanques da entrevista.

O primeiro tema indicou que os produtores partiram do pressuposto de que os adolescentes são indivíduos que procuram interagir socialmente e chamar a atenção dos outros e que, para eles, seria uma necessidade ter o corpo "sarado" e beber, já que esses são requisitos considerados essenciais para a socialização, como pode ser evidenciado numa das falas dos alunos (neste artigo, os nomes dos participantes são fictícios, para preservar sua identidade): “Eneida: E até porque nessa idade a pessoa começa a querer se enturmar, sair, aparecer um pouco mais, se destacar, então algum método que os adolescentes possam estar usando pra isso...".

Esse entendimento dos produtores sobre os valores que são priorizados pelos adolescentes levou o grupo a optar por editar um vídeo que falasse dos anabolizantes e do álcool e de suas consequências para o organismo, embora também tenham pensado em falar sobre sexo (mas acharam já ser algo "passado") e sobre cicatrização. A ideia inicial foi, no entanto, reforçada pelo fato de que dois alunos já haviam observado no seu cotidiano o uso de anabolizantes por adolescentes, além de perceberem o uso frequente de bebidas alcoólicas nos mesmos meios. Entenderam que atingir um público adolescente, que era seu alvo principal, não é muito fácil. Para conseguirem, então, que a mensagem alcançasse esses jovens, seria necessário, pelo entendimento do grupo, ser "apelativo" e/ou "impactante", além de usar linguagem simples e do contexto cultural do público-alvo, para não 
deixar que o vídeo ficasse maçante, como expresso nas seguintes falas dos alunos:

Joana: a gente tinha objetivo também de até ser um pouco apelativo mesmo, no vídeo, pra colocar imagens que chocassem, porque é o que eles falaram ali, o adolescente consegue ser tão frio, até o ponto de falar é, a gente viu esse vídeo aqui, agora vamos beber pra esquecer o que a gente viu (risos).

Maria: E a gente também procurou colocar uma linguagem assim, deles mesmos, pra eles prestarem atenção, até porque pra não ficar maçante...

No segundo tema, os produtores enfatizaram como sendo o significado preferencial as consequências das atitudes individuais. Para eles, o vídeo também pretendia levar os alunos à reflexão, à crítica e à responsabilidade e, por isso, teria uma função educativa, evidenciada nas falas a seguir:

Eneida: A gente mostrou o que é e aí, a partir daí, a pessoa atua; então a gente tem uma consciência de ele refletir e eles tirarem suas próprias conclusões.

Sandra: E a gente tá ali tentando, como professores, formar adultos jovens responsáveis, pelo menos vamos tentar fazer isso. Passar para eles não simplesmente só a matéria ali, da biologia, da matemática, da física, mas sim, do que é certo.

O terceiro tema que emergiu da entrevista está relacionado às escolhas dos recursos utilizados na produção do vídeo, visando endereçá-lo a adolescentes, e à correta realização desse endereçamento. Uma experiência anterior malsucedida de alguns dos produtores levou o grupo a escolher imagens e vídeos profissionais disponíveis na internet, na tentativa de fazer um vídeo melhor do que aquele anteriormente produzido.

O recurso apontado como mais importante pelo grupo foi o sonoro, as músicas, que deveriam ser conhecidas do público, instrumentais, para não desviarem a atenção do aluno, e impactantes, para prenderem sua atenção. A escolha das imagens recaiu nas consideradas mais "interessantes" e "impactantes" na opinião do grupo e nas contrastantes, ou seja, que explorassem "os dois lados da moeda", como dito por um dos alunos. A escolha de fotografias de jovens artistas também foi, de acordo com os estudantes, uma forma de reforçar o endereçamento. $\mathrm{O}$ grupo também procurou utilizar material do cotidiano dos alunos, pois acreditaram que isso lhes facilitaria a compreensão.

Outra preocupação que tiveram, na tentativa de acertar o endereçamento do vídeo, foi em relação ao seu tempo de duração, que deveria ser curto, por acreditarem que os adolescentes são impacientes e "querem tudo rápido". Mais uma vez, enfatizaram a preocupação em não deixar que o vídeo por eles produzido ficasse maçante. A fala de um dos alunos mostra sua opinião a esse respeito:

Paulo: A gente tava preocupado também com o tempo. E assim, se a gente já tem impaciência com dez minutos, imagina o jovem de hoje, que quer tudo muito rápido. Então, foi uma questão que preocupou muito, a questão do tempo. Fazer uma coisa dinâmica, ao mesmo tempo que não ficasse maçante. 


\section{Sobre a recepção do vídeo}

Antes de o vídeo escolhido ser novamente apresentado à turma, foi pedido aos espectadores que redobrassem sua atenção, tendo em vista que, após a apresentação, responderiam a um conjunto de perguntas sobre a produção para avaliá-la. Após a reapresentação do vídeo, os 17 alunos que não participaram de sua elaboração foram convidados a responder a um questionário. Nem todos o responderam de forma completa.

Pela análise das respostas à primeira pergunta - que objetivava saber, na opinião dos espectadores, qual o significado preferencial do vídeo segundo o grupo de produtores, ou seja, o que este grupo pensou que os alunos deveriam entender preferencialmente -, percebemos que a leitura preferencial feita pelos espectadores não correspondeu exatamente ao significado preferencial pensado pelos produtores. Dentre os 17 alunos que responderam ao questionário, 14 indicaram o "alerta para os riscos do uso de anabolizantes e álcool", o que nos levou a concluir que esta era entendida por eles como a sua leitura preferencial.

A segunda pergunta objetivava saber se o grupo produtor havia sido bem-sucedido em sua intenção, na opinião dos espectadores, e verificar se estes foram capazes de identificar, no vídeo, marcas que levassem ao sucesso de comunicação da mensagem pretendida por seus autores. Verificamos que os espectadores citaram os mesmos recursos pensados pelos produtores como os que permitiriam mostrar com eficiência o significado preferencial do vídeo a seu público. O tipo de imagens e a linguagem adotada foram o que mais chamou a atenção dos espectadores como recursos importantes para o sucesso do vídeo entre os adolescentes. As respostas mais comuns a essa pergunta foram: "porque tem imagens reais/ interessantes/ chamativas/ impactantes"; "porque tem linguagem direta e de fácil compreensão"; e "porque equilibrou música/ imagens/ escrita". No entanto, foram percebidas falas de alguns poucos alunos que indicaram ter o vídeo um impacto momentâneo sobre o público e que aquele tipo de produção não conscientizaria o espectador.

A terceira pergunta pedia que os alunos identificassem e justificassem as escolhas (de narrativa, dramaturgia, recursos, expressões linguísticas, sons, músicas, etc.) que o grupo havia feito para que o vídeo atingisse os objetivos propostos e os elementos que indicassem que ele foi produzido para alunos de Ensino Médio. Pretendeu-se, assim, investigar se os espectadores reconheciam marcas no vídeo que confirmassem seu endereçamento para esses alunos. Das marcas reconhecidas pelos espectadores, a maioria coincide com as escolhas feitas pelos produtores, como, por exemplo, as músicas (11 em 17 alunos) e as imagens impactantes (nove em 17 alunos) como recursos que facilitariam o endereçamento do vídeo a adolescentes. Tanto quanto os produtores, os espectadores também acharam que os temas escolhidos (anabolizantes e bebidas alcoólicas), por estarem "em alta”, "já direcionam" e atrairiam facilmente o interesse dos adolescentes.

A quarta pergunta solicitava a opinião dos alunos sobre a adequação das escolhas feitas pelos produtores para transmitir a mensagem pretendida, tendo 
em vista os conhecimentos que tinham adquirido sobre processos audiovisuais. Pretendia investigar se os espectadores acreditavam que os produtores haviam feito escolhas adequadas na construção do significado preferencial. Embora 14 dos espectadores acreditassem que os produtores tinham acertado em suas escolhas, por conta dos recursos que usaram na produção do vídeo, verificamos que dois responderam que não acreditavam e citaram como uma das razões o fato de as imagens escolhidas causarem sensibilidade apenas momentânea. Além disso, um dos alunos disse não gostar das imagens apresentadas, o que representa uma postura de distanciamento em relação ao vídeo.

Para a quinta questão, que perguntava "se" e "o que" os alunos fariam de forma diferente no vídeo, alguns alunos apresentaram, individualmente, as seguintes respostas: poderiam ter variado mais nas músicas; as fotos poderiam ser mais objetivas e sem "cenas feias"; poderiam mostrar os motivos dos jovens em usar essas substâncias; mostrar a bebida como normal em doses pequenas. Essas respostas mostram que esses alunos mantiveram alguma distância crítica em relação ao vídeo e fizeram uma leitura negociada, não tendo total adesão à perspectiva dos produtores.

Quanto à observação da apresentação do vídeo, foi possível perceber que, durante a exibição da seção relacionada ao consumo de álcool, os alunos riram muito e fizeram muitas brincadeiras, como correlacionar a caricatura de um bêbado a um dos colegas da turma e comentar que, após o vídeo, teriam que ir beber para esquecer. O fato de uma aluna ter dito o seguinte sobre um colega: ele "está indo neste mesmo caminho de uso de anabolizantes"; pareceu mostrar que ela atribuía ao vídeo certa proximidade com a realidade.

Foi igualmente notável a manifestação de adesão dos alunos às músicas escolhidas pelos produtores. Quando estas começaram a ser tocadas, vários alunos dançaram sentados em suas carteiras, balançando os braços sobre suas cabeças. Houve também grande entusiasmo da turma com as fotos dos artistas que apareceram, especialmente para a maioria feminina da turma. O alvoroço foi grande quando apareceram as fotos de rapazes. Uma delas brincou: "Uhu! Colírio pros olhos!”.

Alguns fizeram comentários como "que horror!” e “eca!” quando viram homens e mulheres muito musculosos. Alguns ficaram chocados com as cenas mais fortes, já que viraram o rosto ou fecharam os olhos, indicando incômodo com as mesmas. Uma aluna chegou a dizer: "Ah, não é bom passar isso de novo não, vamos pular! Ah, tem que passar o final de novo? Não, vamos pular (o final). Para o vídeo!".

\section{DISCUSSÃO}

Como apresentamos na seção Marco teórico deste trabalho, não existe uma obrigatória identidade entre os sentidos produzidos no polo da produção e as 
leituras obtidas no polo da recepção de produtos de mídia. Mesmo que as leituras feitas pelos espectadores sejam, até certo ponto, condicionadas pelas intenções dos produtores, objetivadas na construção do texto midiático, os espectadores fazem uma leitura ativa deste texto, podem ajustá-lo, ressignificá-lo de acordo com sua experiência sociocultural.

Trataremos a seguir, então, da discussão quanto à identificação do significado e da leitura preferenciais, do endereçamento, da identificação do modo de leitura do vídeo e descreveremos e analisaremos brevemente as posições de leitura adotadas pelos espectadores nas dimensões indicadas inicialmente.

\section{Significado e leitura preferenciais}

De acordo com a análise que fizemos e devido às escolhas feitas na edição do vídeo e ao tempo dedicado a cada seção do mesmo, o significado preferencial que se observou foi "esteroides anabolizantes e álcool causam danos à saúde e à vida humanas. Estas substâncias não devem ser utilizadas. Um corpo ‘sarado’ pode ser obtido com alimentação saudável e exercícios físicos”. No entanto, para os produtores, seria: "atitudes trazem consequências, temos controle das nossas atitudes; o corpo tem defesas naturais".

Em relação à leitura preferencial, a maioria dos 17 espectadores indicou que a mensagem pretendida era "alertar para os riscos e mostrar as consequências para a saúde do uso de anabolizantes e álcool", enquanto alguns acreditaram que era "fazer os alunos pensarem sobre seus atos", o que se distancia em parte do significado preferencial pensado pelos produtores.

\section{Posições e dimensões de leitura}

Após análise da sessão de exibição do vídeo e das respostas dadas ao questionário, foi possível identificar as posições de leitura (HALL, 2003a) adotadas pelos espectadores. Essa análise nos fez acreditar que a maioria dos alunos adotou uma posição negociada de leitura, na qual o espectador decodifica a mensagem dentro de um "espaço negociado", preenchido por diferentes posições situadas entre o significado preferencial e a leitura de oposição. Essa leitura negociada foi observada em falas de alunos que expressaram que os produtores poderiam ter variado mais nas músicas; que as fotos poderiam ser mais objetivas e sem "cenas feias"; que deveriam mostrar os motivos dos jovens para usar essas substâncias, além de mostrarem a bebida como normal em doses pequenas.

Em relação às dimensões de leitura (SCHRØDER, 2000) adotadas pelos alunos na dimensão de compreensão, percebeu-se que a maioria dos espectadores adotou uma posição intermediária entre a monossemia total e a polissemia. Isso ficou evidente ao observarmos que 14 alunos entenderam que o significado preferencial era "alertar para os riscos e mostrar as consequências para a saúde do uso de anabolizantes e álcool" e que, para dois alunos, seria "fazer os alunos pensarem sobre seus atos". Ambas essas compreensões estão mais próximas do significado preferencial tal como ele foi identificado pelos analistas, contudo, se afastam do 
que os próprios produtores pretenderam como sendo o significado preferencial.

Já na dimensão de discriminação, percebeu-se que a maioria dos alunos adotou uma postura de imersão/não distanciamento do vídeo quando enxergaram que o grupo foi bem-sucedido na produção do vídeo, por ele conter imagens interessantes, chamativas e impactantes, linguagem de fácil compreensão, porque equilibrou música/imagens e escrita. No entanto, encontramos alguns poucos alunos que adotaram uma postura de imersão fraca/distanciamento do vídeo, ao indicarem que seu impacto era apenas momentâneo, que não gostaram das imagens apresentadas e que o vídeo não conscientizava. Além disso, alguns alunos ainda disseram, como vimos, que as fotos poderiam ser mais objetivas e que o vídeo poderia mostrar os motivos dos jovens para usar aquelas substâncias. Isso mostrou algum distanciamento crítico, que aponta que esses alunos não aderiram inteiramente ao que o vídeo propunha na dimensão de discriminação, mostrando alguma resistência ao material.

\section{Endereçamento}

A análise do vídeo nos deu algumas evidências sobre marcas que indicavam quem era seu público preferencial. Uma primeira evidência foi a tentativa de diálogo direto com o espectador, que se pôde notar no uso de expressões do vocabulário do jovem e de algumas frases imperativas e em segunda pessoa (pronome "você"), como as citadas acima. Outra evidência foram as imagens de jovens artistas apresentadas e as músicas escolhidas, que não só têm alguma relação com os temas e o ritmo do vídeo, mas, principalmente, são apreciadas por adolescentes. Esses elementos indicaram uma preocupação em utilizar referências comuns aos adolescentes, referências que façam parte de seu cotidiano e de seus interesses.

A entrevista com os produtores confirmou o fato de essas escolhas terem se constituído como forma de endereçar o vídeo a adolescentes. Os produtores deram mais importância, em primeiro lugar, às músicas e, em segundo lugar, às imagens. Informaram, ainda, que procuraram usar imagens interessantes, mas também impactantes, para chamar a atenção dos adolescentes, por os considerarem "frios", "indiferentes".

Ainda de acordo com os produtores, a escolha dos temas "anabolizantes" e "bebidas alcoólicas" se deveu ao fato de estarem na moda entre os adolescentes, o que os faria naturalmente se interessar pelo vídeo. Os autores ainda citaram a preocupação com a duração do vídeo, que deveria ser curto, devido à impaciência "natural" dos adolescentes e para que o vídeo não ficasse maçante.

Ao ser comparada a fala dos produtores com o que foi indicado pelos espectadores, percebe-se que, para estes últimos, a escolha dos recursos com vistas ao endereçamento proposto foi acertada. Os espectadores enfatizaram a adequação do endereçamento citando a trilha sonora atual, as imagens impactantes, os temas e as fotos de celebridades jovens, o que coincidiu com o que foi dito pelos produtores e com a análise do vídeo. Quanto às imagens consideradas impactantes pelos produtores, podemos entender que esse recurso de endereçamento não foi 
totalmente aceito, já que alguns alunos as rejeitaram claramente.

\section{Modo de leitura}

Depois de analisar o vídeo escolhido e o contexto de sua exibição, e utilizando os conceitos de Odin (2005), concluímos que foi adotado principalmente o modo estético de leitura. Neste modo, o espectador vê o filme se interessando pelo trabalho feito com as imagens e com os sons. Como, antes da exibição do vídeo, o professor pediu atenção máxima, pois os espectadores deveriam avaliá-lo respondendo a um conjunto de questões, esta pode ser considerada uma das condicionantes para que os espectadores tenham adotado esse modo de leitura.

Esse modo ficou bastante evidente, pois houve, durante a exibição do vídeo, predomínio de comentários (positivos ou negativos) sobre os recursos estéticos utilizados no vídeo, como visto anteriormente. Vários alunos comentaram ou concordaram, no fim, com a opinião de que o vídeo foi muito benfeito e que seria bom para os adolescentes "acordarem", enquanto alguns criticaram a escolha de imagens com cenas fortes - capazes de chocar os espectadores -, indicando que eles mesmos sentiram incômodo e que viraram o rosto ou fecharam os olhos diante delas.

Deve-se ter em vista ainda que o vídeo escolhido foi visto por todos os alunos dessa turma, em sala de aula, que todos já se conheciam e faziam parte do mesmo grupo e que todos os vídeos foram previamente apresentados, permitindo que cada grupo observasse a produção dos demais. Além disso, a produção e a apresentação do vídeo foram atividades da disciplina das quais todos deveriam participar. Seu conteúdo biológico era do conhecimento de todos, e os vídeos apresentados pouco acrescentaram a este conhecimento prévio. Assim, notamos que outro modo de leitura adotado, embora em menor grau, foi o modo privado, já que este modo é encontrado quando se vê um filme voltando-se para sua vivência e/ou a de um grupo ao qual se pertence, reforçando a identidade de grupo ou de indivíduo.

Esse modo de leitura ficou mais evidente quando observamos, durante a exibição da última seção, relacionada ao consumo de álcool, que os espectadores fizeram muitas brincadeiras, como correlacionar cenas do vídeo com colegas da turma, rir, dançar e comentar que, depois do vídeo, teriam que beber para esquecer, dentre outras falas e ações, conforme visto acima.

\section{CONCLUSÕES}

Este estudo procurou evidenciar como mesmo a produção de um vídeo com intenções educativas explícitas, e para um público determinado, está imersa em indeterminações. A articulação entre os estudos da produção deste vídeo e da sua recepção por um grupo com características similares às do que o produziu mostrou, por um lado, que as intenções dos produtores nem sempre se apresen- 
tam claramente para os seus futuros espectadores e, por outro, que estes podem fazer leituras distintas, ainda que bastante convergentes e aderentes, ou até mesmo leituras que se abrem a perspectivas críticas e/ou resistências.

O estudo do significado preferencial do vídeo mostrou que houve diferenças entre o que os produtores pensaram expressar e o que os analistas (sejam os pesquisadores, sejam os espectadores) compreenderam. O estudo do endereçamento, por sua vez, apontou que as escolhas estéticas e narrativas adotadas pelos produtores pareceram, em geral, adequadas ao público visado, ainda que isso só possa ser confirmado por pesquisa com representantes deste público (estudo em andamento). Por outro lado, o estudo da recepção mostrou que a maior parte dos espectadores sujeitos da pesquisa aderiu e adotou uma postura mais claramente convergente ao posicionamento implicitamente apoiado pelo vídeo. Significativamente, no entanto, houve também manifestações de crítica e resistência ao vídeo, especialmente no que diz respeito à abordagem do tema (por exemplo, a sensibilidade apenas momentânea causada).

Esses resultados nos mostram, pelo menos em parte, que o uso educativo de vídeos não é uma atividade transparente, que o processo comunicativo não é linear e é problemático mesmo no âmbito da produção, já que os próprios produtores não têm controle absoluto sobre a clareza ou a diretividade de suas escolhas e construções.

Que implicações tais constatações teriam para o ensino de ciências com recursos audiovisuais? O que significa para o ensino-aprendizagem de ciências com vídeo a constatação de que o aluno é um sujeito ativo na leitura desse tipo de material? O que significam para a produção de vídeos educativos as suposições que são feitas pelos produtores sobre seus prováveis espectadores? Que problemas essas suposições podem causar? Neste estudo, não foi possível responder a essas questões, que permanecem abertas a futuras investigações, mas foi possível perceber que os lugares construídos para o espectador ocupar em trabalhos com vídeos educativos podem ser diversamente reconfigurados por ele.

\section{NOTAS}

${ }^{1}$ Apoio: (1) JCNE/FAPERJ, (2) CNPQ Grupo de pesquisa: (3) GERAES (NUTES - UFRJ)

Site: http://www.nutes.ufrj.br/geraes/E-mail: geraes@nutes.ufrj.br

${ }^{2}$ Requiem for a Dream ("Réquiem para um Sonho" - título no Brasil ou "A Vida Não É um Sonho" - título em Portugal) é um filme estadunidense de 2000, do gênero drama, dirigido por Darren Aronofsky. (Baseado em: <http://pt.wikipedia.org/wiki/Requiem_for_a_Dream>).

${ }^{3}$ LMFAO foi um grupo americano de rap e eletro hop oriundo de Los Angeles, Estados Unidos. O grupo refere-se ao seu estilo de música como "Party rock". LMFAO, além de ser uma banda, é também um estilo de vida levado pelos "Party Rockers" (Baseado em: < http://pt.wikipedia.org/ wiki/LMFAO $>$ ). 
${ }^{4}$ Coldplay é uma banda britânica de rock alternativo fundada em 1996, na Inglaterra. A banda passou a se chamar "Coldplay" apenas em 1998 e já vendeu mais de 50 milhões de discos em todo o mundo (Baseado em: <http://pt.wikipedia.org/wiki/Coldplay>).

\section{REFERÊNCIAS}

ARROIO, A.; DINIZ, M.L.; GIORDAN, M. A utilização do vídeo educativo como possibilidade de domínio da linguagem audiovisual pelo professor de ciências. In: ENCONTRO NACIONAL DE PESQUISA EM EDUCAÇÃO EM CIÊNCIAS (ENPEC), 5., 2005, Bauru. Atas... Bauru: Abrapec, 2005. p. 1-10.

ARROIO, A.; GIORDAN, M. O vídeo educativo: aspectos da organização do ensino. Química Nova na Escola, São Paulo, n. 24, p. 8-11, nov. 2006.

BARDIN, L. Análise de Conteúdo. São Paulo: Edições 70, 2011. 229 p.

DEACON, D. Holism, communion and conversion: integrating media consumption and production research. Media, Culture \& Society, v. 25, n. 2, p. 209-231, 2003.

ELLSWORTH, E. Modos de endereçamento: uma coisa de cinema. In: SILVA, T. T. (Org.). Nunca fomos humanos: metamorfoses da subjetividade contemporânea. Belo Horizonte: Autêntica, 2001.

FERRÉS, J. Vídeo e Educação. Porto Alegre: Artes Médicas, 2. ed.,1996.

HALL, S. (2003a) Reflexões sobre o modelo de Codificação/Decodificação (entrevista com Stuart Hall). In: SOVIK, L. (Org.). Da diáspora. Belo Horizonte: UFMG, 2003. p. 353-386.

. (2003b) Codificação/Decodificação. In: SOVIK, L. (Org.). Da diáspora. Belo Horizonte: UFMG, 2003. p. 387-404.

LEAL, O. F. Etnografia de audiência: uma discussão metodológica. In: SOUZA, M. (Org.). Sujeito, o lado oculto do receptor. São Paulo: Brasiliense, 1995. 231 p.

MORLEY, D. Interpretar televisión: la audiencia de Nationwide. In: Televisión, audiencias y estudios culturales. Buenos Aires: Amorrortu, 1996. p. 111-147.

PASTOR JUNIOR, A. A.. Recepção Audiovisual na Educação Médica: leituras de um vídeo de Psicologia Médica. 2012. 186p. Dissertação (Mestrado em Educação em Ciências e Saúde) - Núcleo de Tecnologia Educacional para Saúde, Universidade Federal do Rio de Janeiro, Rio de Janeiro, 2012. 
ODIN, R. A questão do público: uma abordagem semiopragmática. In: RAMOS, F. (Org.). Teoria Contemporânea do Cinema (vol. II). São Paulo: Senac, 2005. p. 27-45.

SCHRØDER, K. Making sense of audience discourses: Towards a multidimensional model of mass media reception. European Journal of Cultural Studies, v. 3, n. 2, p. 233-258. Sage: 2000 .

WORTH, S. The Uses of Film in Education and Communication. In: Larry Gross (Ed.). Studying Visual Communication. Philadelphia: University of Pennsylvania Press, 1981. cap. 4, p. 108-133.

Data de recebimento: 03/05/2014

Data de aprovação: 10/02/2015

Data da versão final: 03/05/2015

\section{Contato:}

Wagner Gonçalves Bastos

Rua Dr. Francisco Portela, 1470 - Bloco B - Patronato

Cep 24435-005 - São Gonçalo - Rio de Janeiro - Brasil

E-mail: wgnutes@gmail.com 